\title{
The Neonatal Unit
}

\author{
Elaine Wilson, R.N., R.M., Certificate in \\ Ward Administration and Clinical Teaching
}

Senior Sister, Neonatal Unit, Groote Schuur Maternity Hospital, Cape Town.

\section{OPSOMMING}

Die neonatale eenheid behoort só beplan te wees dat dit onnodige toegang uitskakel. Dit behoort verskillende versorgingsafdelings te hê om vir verskillende vlakke intensiewe verpleegsorg voorsiening te maak.

Gespesialiseerde sorg word verkieslik in 'n groot enkelkamer verskaf, maar opnames in die afdeling behoort eers in ' $n$ afsonderlike kamer aandag te kry. Hulpdienste behoort binne die neonatale eenheid of in die onmiddellike nabyheid van die neonatale intensiewe sorgeenheid geplaas te wees. Om die spanning van die versorging van ernstig sieke pasgeborenes te verminder, is voldoende personeel nodig, en bewakingstoestelle behoort as hulp aan die versorgers verskaf te word.

Met die oog op die gespesialiseerde aard van die werk in 'n intensiewe versorgeenheid, behoort personeel die regte opleiding daarvoor te kry.

" $\mathbf{H}$ ISTORICALLY, there has been a change in attitude toward the new born from one of resigned acceptance of neonatal mortality rates of the order of $100-200 / 1000$ births to one of intense concern for survival which is now being tempered to a more balanced concern for quality survival", 1 .

In the past a very small preterm infant might be left unattended and only be given treatment after a few hours of birth if he continued to show signs of survival. To commence treatment at this stage of his life is too late! His chance for normal development might have been impaired during this period of neglect. The key to quality survival is the institution of optimal care for infants in need of such care. And this can best be done in a neonatal intensive care unit (NICU).

The purpose of this paper is to describe the components of such a NICU, and how it should function. The NICU, plus other areas of newborn care together form the neonatal unit or nursery.

\section{AREAS OF NEWBORN CARE}

Before discussing the NICU, it is important to very brietly point out the different areas of newborn care in a maternity hospital. These are designed to provide nursing care of graded intensity, depending on the level of risk of each newborn. Movement of infants from one area of care to another will obviously be dictated by the infants themselves.

Normal term infants should remain with their mothers throughout hospitalisation, i.e. "rooming-in". This greatly enhances bonding, and also facilitates instruction of the mother as regards infant care and reduces the incidence of cross infection.

Transitional Care is the assessment and observation of infants at some risk, but not the very sick or small ones.
Infants cared for in this area are those at risk due to the method of their delivery, e.g. Caesarean section or forceps, maternal disease, e.g. diabetes mellitus, by virtue of their low birthweight ( $600-2500$ grms), or if they have suffered moderate asphyxia neonatorum. They receive care for varying periods often not longer than eight hours. The appearance and behaviour of infants in this area determine the type of care that must follow.

The small number of infants who have a delayed or complicated transition are transferred to the NICU, and others to the convalescent area for further care, but the majority are transferred to their mothers within 12 hours where they "room-in".

Convalescent Care is for infants from the NICU and the Transitional Care area as they no longer require constant surveillance, but are of low birthweight and still require incubator nursing.

Pre-discharge area is for infants who have progressed sufficiently to be moved from the convalescent area, but who are not yet ready for home care.

Mothers should visit their inlants I requently in all the areas of care, but once the infant has advanced to this area the mother is expected to remain with the infant during the day in order to handle the baby and to establish breast-feeding. In order for the mother to gain confidence, this arrangement may be continued for a week or longer until discharge. When indicated, e.g. in the case of a very young mother, she should be re-admitted and take care of her baby entirely under the supervision of the stafl. In this way greater conlidence is achieved by the mother and inevitably the bonding process is also enhanced. 
NEONATAL INTENSIVE CARE UNIT

Although only $3 \%-5 \%$ of all newborns will require intensive care, it is imperative (in order that optimal care be rendered), that a good liaison between medical and nursing stalf exists so that the necessary preparation for each infant can be made before delivery according to the problem expected, and a person experienced in neonatal resuscitation be present at the time of birth.

As it is estimated that $60 \%$ of all potential neonatal problems are identitiable before birth, medical and nursing personnel caring for pregnant mothers antenatally and during labour are at an advantage of recognizing problems early. Admissions from other hospitals are best done before delivery as this definitely enhances the outcome for the fetus.

In this context it will be clear that not every maternity hospital should have an NICU, but that a regional or referral system be adopted as described elsewhere ${ }^{2}$

\section{Admissions}

The more common indications for admission to an NICU include:

A birthweight of less than 1600 gram

Respiratory distress

Severe asphyxia neonatorum

Severe Rhesus disease

Recurrent apnoea

Infection

Major congenital abnormalities

Drug depression due to medication administered to mother during labour

Infants requiring exchange transfusion

\section{Physical Facilities}

It is prelerable to attend to admissions in a separate room near the NICU as the many procedures and personnel involved at this time are liable to cause disruption of the routine in the unit and much distraction of the stafi.

Radiant warmers (with infant servo-control) have the advantage of easy access lor providing critical care, but longterm use is contra-indicated as the chance of bacterial contamination increases. Specialised care is prelerably administered in a single large room - large enough to accommodate all the necessary equipment and personnel.

The ideal location is in a maternity hospital, as near to the labour ward as possible, and away from routine hospital tralfic to minimize delay in transfer and the hazard of infection. It should be easily reached from the ambulance entrance.

Viewing windows from the corridor are lor ollicials or other visitors who have no need to enter the actual in lant care area. This does not apply to parents who are allowed in so that they can handle their infants.

Because a large number of nursing, medical and paramedical personnel are normally in this area, ample space should be allocated to each inlant care station. Equipment used for monitoring the inlant and for giving supportive therapy requires space, therefore an average of $9 \mathrm{~m}^{2}$ is recommended per infant. There should be $2 \mathrm{~m}$ between incubators and the aisles should be $2,5 \mathrm{~m}$ wide ${ }^{3}$.

Cupboard, desk and sink space must be provided. The NICU should be a pleasant room with low windows to lessen the impact of isolation from the outside world.

At each patient care station a minimum of 8 - 10 electrical outlets is required, also two oxygen, one compressed air and one suction outlet.
In addition to adequate lighting from fluorescent tubes in the ceiling, there should be an adjustable anglepoise lamp suspended above each incubator.

Because temperature control in the room is more difficult to achieve with windows in the outer walls, it is felt that windows should have double glazing in the units where climate is more temperate. There should be a scrub area for staff to use before entering the NICU. In addition, a sink with foot or knee controls to serve four patient stations minimizes the distance the nurse walks.

A cupboard with a work top adjacent to each incubator allows the nurse (and other stafif) to write daily notes, etc., and also serves for storage of equipment, thereby minimizing the walking distance, allowing the nurse to remain in the area to which she was assigned. An intercom system with the labour ward, and the other areas of care makes provision for easy communication.

\section{Ancillary Services}

These should be in close proximity to the NICU, and other areas of care.

Laboratory Because emergency care is provided there must be laboratory facilities. This is best situated within the neonatal unit, so that immediate results are available, e.g. blood gases and acid base.

Radiology Moving a sick neonate for the purpose of radiology could have hazardous effects on the infant's condition. For this reason a portable X-ray unit is necessary. It is essential that the machine remains in the neonatal unit as urgent diagnosis can often be confirmed by an X-ray film.

Storage Facilities A large storage room is necessary for storing expendable items and respirators, incubators, phototherapy units and so on. Storage should be decentralised to allow access to most items without going into the corridor. However, there is still need for storage at some central supply within the neonatal unit.

A lecture room nearby is necessary for the education of statif and for meetings.

\section{A feed preparation room}

On the same floor is ideal but could elsewhere. Mothers should be encouraged to participate in the care of their sick or immature inlants by expressing their milk. The collection and storage of breast milk is best done by staff attached to the leed preparation room.

A clean utility room is required to set up for procedures and for storing sterile packs. In the event of the feed preparation room being some distance from the neonatal unit, the prepared feeds can be stored in a fridge in this room.

A dirty utility room is for dismantling trolleys and disposing of used articles, and is best located near the exit of the neonatal unit.

Dressing rooms with locker and toilet facilities for nursing stalt to change into clothes they will wear in the neonatal unit

Sleeping quarters with toilet and shower facilities for the doctor on call should be close by, or within neonatal unit.

Offices for the consultant paediatrician should be located within the neonatal unit, and that of the nursing supervisor, (or matron) should be close to the NICU.

The clerk/secretary's station is the control point of patient care activities and should be located near the entrance so that she can supervise traffic and limit unnecessary entry to the unit. There should be a telephone and an intercom.

A parents' room for scrubbing and gowning should be situated near the entrance to the neonatal unit. There should 
be toilet facilities and seating should be provided. Parent interviewing and teaching can be done in this area as well.

\section{NURSING STAFF}

A nursing supervisor should be in overall charge in the NICU. The nurse to patient ratio should be $1: 1,5-2^{4}$. Registered nurses with special neonatal care training should undertake direct care of these infants. Ideally three shifts of 8 hours should be worked. In the transitional, convalescent or pre-discharge areas a lower staff-patient ratio of $1: 5-8$ would be acceptable. Preferably the staff should also have special, neonatal care training, although this would be impossible in practice. Student midwives and student nurses undertaking the integrated diploma and degree course would rotate through these areas.

Of major importance is the fact that the neonatal staff should be relatively fixed and not changed too often.

In view of the demanding nature of the work, especially in the intensive care area, it is important to maintain staff morale at a high level. For their comfort the staff should wear cool cotton frocks, and an open shoe. The warm environment in which they work calls for some form of fruit drink being readily available to them. These are a few examples of small but important concessions.

The provision of seating, e.g. high stools/rocking chairs makes not only for staff comfort while performing tasks such as feeding, but is more likely to ensure that the feeds are given less hurriedly.

Combined regular meetings (e.g. weekly), with nursing, medical and para-medical staff, offer the opportunity of solving problems dealing with irritations or frustrations, e.g. difficulties in working relationships, overcrowded conditions, and shortage of staff. This lends support to emotional situations which arise from e.g. the death of an infant, and keeps lines of communication open.

Leave should be taken twice annually.

\section{Functions of Nursing Staff}

Although a detailed description of the clinical lunctions expected from sisters is not appropriate in this article, the following list provides an indication of what is required:

- Set up and maintain parenteral infusions

- Perform a full physical examination of the infant to screen for abnormalities and assess gestational age

- Identify risk factors from a history

- Undertake resuscitative responsibility which includes: endotracheal intubation

giving mechanical respiration

working respirators

administering oxygen

measuring blood pressure

- Manage thermal environment for the various infants

- Assess daily progress of infants

- Take steps to develop a good parent-infant relationship

The above nursing process is best taught by means of a neonatal care course, but many do not hold such a certificate. It is, therefore, essential that all staff concerned with the care of infants attend an in-service programme of an on-going nature. A person who is specifically released from other duties to provide orientation and instruction is vital to ensure in-service education.

\section{raramedical Staft}

The following personnel are all essential to a large neonatal unit and form part of the work team:
Most high-risk infants are a source of anxiety to the parents and as the social worker is a supportive person, her services are invaluable.

The occupational therapist has an important role to play in the stimulation of certain babies.

The radiographer should be readily at hand when required.

The physiotherapist has a place in the neonatal unit especially for babies receiving ventilatory support.

A laboratory technician should be attached to the neonatal unit in order to speedily perform the various tests and have the results available within minutes.

\section{Equipment}

Direct observation by the nurse is by far the best method of monitoring the infant. However, the use of monitoring equipment has a place in the NICU, as several parameters can be measured simultaneously e.g. heartrate, blood pressure, respiration, temperature. Handling of the intant is minimized once the monitors are attached to the intant and this is especially important in the nursing of infants with hyaline membrane disease. Some infants have a bradycardia before apnoea occurs, and the alert nurse will detect this and stimulate the infant, thereby preventing apnoea. A detailed list of equipment will not be given.

\section{Control of Infection}

Neonates have a predisposition to inlection because of illness and immaturity. Infections are spread by people and fomites and it is the nurse who cares lor the baby constantly who should ensure that there is no slackness concerning hygiene practices, as it could become a serious threat to the infant's survival.

Apart from some procedures e.g. parenteral thuids, medications, and preparation of feeds which require strict sterility one must follow the simple rules of hygiene.

Equipment should be cleaned/disinlected before being put into use on another patient. Use disposable equipment where possible. Breathing circuits and humidifiers should be changed daily when in use. The space between incubators/cots should be sulficient to prevent crossinfection.

Personnel caring for neonates should be free of infections such as 17u, colds, sore throats, diarrhoea and septic toci.

Medical and nursing personnel who are constantly in close contact with infants should change street clothes before going into the neonatal unit. Short sleeve gowns may be worn by personnel who make intermittent contact with the infants

Handwashing is the most important of all measures used to control infection. On entering the neonatal unit the hands and arms should be scrubbed with Hibiscrub or similar solution. The hands should be washed using the same solution before and after handling the infant.

Pedal action bins lined with plastic bags should be used for the disposal of soiled linen and rubbish. These are easily sealed and removed.

In the case of infants who have a communicable disease, e.g. gastro-enteritis, it is essential to isolate the infant to prevent spread of infection to the other intants. Even though this happens very rarely, it is essential to reserve a room for the isolation of such cases. 


\section{CONCLUSION}

The nurse is the key person in caring for the newborn and without her no neonatal unit could function. Despite all the technological advances in electronic devices and all other types of equipment available in the major teaching hospitals, the statement that "The nurse is in a better position than anyone else to detect the subtle signs that often herald catastrophe" remains true ${ }^{5}$. Together with all the other categories of staff, they form a team whose aim is to ensure the best possible outcome for each baby.

The exacting nature of this type of nursing needs national recognition and every encouragement, including better staf- fing. Only thus will we ensure the future health of all our citizens.

\section{REFERENCES}

1. Swyer, P.R.: Neonatology, p. 16; Ed. Avery, G.B. J.B. Lippincott Company. Philadelphia. 1975.

2. Malan, A.F. (1975): The Need for regional Planning of Peri-natal Care. S. Afr. Med. J. 49, 1963.

3. Hospital Care of Newbom Infants. 6th Edition. American Academy of Pediatrics, Illinois. 1974.

4. Idem.

5. Korones, S.B. (1976): High-risk Newborn Infants. 2nd Edition. C.V. Mosby Company. St. Louis. 1976. 